\title{
CLINICAL DECISION-MAKING OF ANESTHESIOLOGY RESIDENTS IN EMERGENCY MEDICAL CARE
}

\author{
Tomas Maceina', Gintautas Valickas, Jūrate Šipylaitė \\ Vilnius University, Lithuania \\ Andrius Macas \\ Lithuanian University of Health Sciences, Lithuania \\ Jevgenija Olševska \\ Center of Anaesthesiology, Intensive Care and Pain Treatment at Vilnius University Hospital Santariskiu Clinics, \\ Lithuania \\ Pranas Puidokas \\ Public institution Centro Outpatient Clinic, Lithuania
}

Abstract. Background. The purpose of current work is to clarify characteristics of anesthesiologists' use of heuristics in emergency medical care. Two separate studies were carried out to evaluate the characteristics of anesthesiologists' use of heuristics: (a) according to gained experience; (b) and under stressful conditions. Methods. First (longitudinal design) study was comprised of two phases 10-11 months apart. In both phases, participants solved three vignettes that required the provision of emergency medical care. In the second study, participants solved three medical vignettes under stressful conditions (i.e. under the influence of the cold pressor test). Physiological data - participants' heart rate - was registered using finger plethysmograph before and after the cold pressor test. The adequacy of decisions were evaluated independently by two experts in anesthesiology. Results and conclusions. Results of quantitative content analysis of the first longitudinal design study showed a decrease in the use of availability and an increase in anchoring and adjustment of heuristic as anesthesiology residents become more experienced. Results of both studies indicate that $32-38 \%$ of all anesthesiology residents' thoughts are heuristic in nature and $3-11 \%$ of all thoughts are cognitive errors.

Keywords: clinical decision-making, heuristics, cognitive errors.

\footnotetext{
${ }^{1}$ Address for correspondence: Vilnius University, Faculty of Philosophy, Department of General Psychology. Universiteto st. 9/1, LT-01513 Vilnius, Lithuania. Phone: + 3705266 7605. E-mail: tomas.maceina@fsf.vu.It
} 


\section{INTRODUCTION}

Anesthesiologists play a significant role in providing emergency medical care. It is incumbent upon them (1) to perform various anesthesia procedures according to different types of surgery, and (2) to identify and diagnose critical medical conditions. Decisions that are made in emergency departments are of utmost importance regarding patients' health. A large number of deaths resulting from erroneous decisions might be avoided if only a better understanding about doctors' decision making processes is sought.

Dual-process theories (Evans, 1984; Reyna \& Brainerd, 1995; Sloman, 1996) in the fields of both contemporary cognitive and social psychology propose an explanation about human decision making mechanisms. What all dual-process theories have in common is their attempt to distinguish two types of information processing, i. e. type 1 and type 2 cognitive processes (Evans \& Stanovich, 2013). Typical correlate of type 1 processes is fast, automatic and associative information processing which does not require any working memory capacity. From a standpoint of Evans (1984) heuristic-analytic theory of reasoning, type 1 processes correspond to heuristic information processing. Heuristic information processing is conceptually compatible with decision making using mental shortcuts, i.e. heuristics (Tversky \& Kahneman, 1974; Kahneman, 2003). Typical correlate of type 2 processes is slow, controlled and rule-based information processing which requires working memory capacity and mental simulation.

Despite the fact that heuristics increases the speed and decreases the effort of information processing, it does not necessarily cause erroneous decisions (McLaughlin, Eva \& Norman, 2014). The use of heuristics in a context of critical and time-limited circumstances can be beneficial because the duration of decision making process decreases. On the other hand, heuristic information processing makes detailed analytic response comparison unlikely. Therefore, the probability to make erroneous decisions, i.e. cognitive errors, increases. These decision making principles can be also applied in emergency care settings. The last two decades mark an increasing interest in the use of heuristics in medical decision making generally (Buckingham \& Adams, 2000; Marewski \& Gigerenzer, 2012) and in the field of anesthesiology specifically (Croskerry \& 
Nimmo, 2011; Stiegler \& Tung, 2014). This is because anesthesiologists often face critical circumstances requiring urgent medical care, and thus have to make decisions immediately.

Despite efforts to clarify the characteristics of anesthesiologists' decision making, a number of problems still remain untackled. To our knowledge, only one empirical study examined anesthesiologists' use of heuristics in emergency situations (Stiegler, Neelankavil \& Dhillon, 2012). In addition, although it is known that decision making can vary according to the level of expertise (Croskerry, 2009a) or stressful conditions (Starcke \& Brand, 2012), no study to date has aimed to clarify relationship between above mentioned factors and anesthesiologists' use of heuristics.

\section{THE USE OF HEURISTICS AND CLINICAL EXPERIENCE}

Doctors and residents base their decisions on the acquired knowledge which is specific to their medical field of expertise. Cognitive psychologists agree that all human knowledge is stored in memory by mental representations (Rumelhart \& Ortony, 1977), e.g. schemata and scripts (Schank \& Abelson, 1977). Unlike schemata which is bounded to store only factual information about the world, scripts are able to integrate this information into meaningful chronological sequences. Therefore, knowledge which is represented by scripts contains additional information about coherence between certain actions and situations (Schank, 1982). Most of doctors' decision making relies on scripts. This is because the diagnosis and treatment of a patient requires understanding and implementation of a specific series of sequential steps.

It is agreed that qualitatively new scripts (which eventually become activated automatically) are being formed in doctors' memories as medical experience increases (Schmidt, Norman \& Boshuizen, 1990; Schmidt \& Boshuizen, 1993; Charlin, Boshuizen, Custers \& Feltovich, 2007). Therefore, it could be assumed that as medical specialists become more experienced, they are more likely to rely on heuristic type 1 processes while making decisions in their field of expertise. For example, the results of Mamede and colleagues (2010) (study with a between-subjects design) showed that compared to the less experienced counterparts, more experienced internal medicine residents were more likely to rely on 
an availability heuristic while making decisions. However, little is known about the use of other heuristics, such as anchoring and adjustment or representativeness (Tversky \& Kahneman, 1974; Croskerry, 2002; Stiegler \& Tung, 2014). Finally, lack of longitudinal (study with a withinsubjects design) studies prevents us from making conclusions about dynamics oftheuse ofheuristicsaccording togained experienceinthefield of emergency medicine.

\section{THE USE OF HEURISTICS UNDER STRESSFUL CONDITIONS}

Anesthesiologists face various difficulties (e.g. limited time and lack of information about patients' condition) associated with provision of emergency medical care. All these circumstances provoke stress, which in turn may have an impact on the quality of decision-making (Kain et al., 2002). There is psychological as well as neurobiological evidence supporting this idea. Over the last decade, the topic of decision making has attracted researchers from the science of neurobiology. Significant amount of data has been accumulated to show that type 1 and type 2 processes are associated with the activity of different regions of the cerebral cortex (Lieberman, 2000; Lieberman, 2007). In addition, results from studies using functional neuroimaging show that stress induced neurobiological processes affect specific regions of the cerebral cortex that are associated with decision making (Kim \& Diamond, 2002; Pruessner et al., 2010; Starcke \& Brand, 2012).

Proponents of dual-process theories agree that decision making under stressful conditions is more likely to be determined by the heuristic type 1 cognitive processing (Evans, 2008; Croskerry, 2009b). However, to our knowledge, no empirical studies to date have examined anesthesiologists' use of heuristics under stressful conditions. This problem also raises other important issues. For example, it is not clear to what extent anesthesiologists rely on heuristics to make their decisions, which heuristics are used the most, and what number of heuristics may be optimal to make the most efficient decisions under stressful conditions.

Considering the lack of empirical research examining anesthesiologists' use of heuristics, current work is aimed at exploring this issue 
particularly in a context of emergency medical care. Our research had two objectives:

1) to evaluate the dynamics of the use of heuristics by anesthesiology residents according to gained clinical experience (first study);

2) to evaluate the use of heuristics by anesthesiology residents under stressful conditions (second study).

\section{STUDY 1}

\section{METHODS}

\section{Participants}

29 anesthesiology residents (working at Vilnius University hospital Santariskiu Clinics and Republican Vilnius University hospital) participated in the first phase of this longitudinal design study. The number of participants dropped from 29 to 19 in the second phase of this study (there was a 10-11-month difference between the first and the second phase of the study). Seven participants did not proceed to the second phase of the study because at that time they were continuing their medical practice abroad, three - declined further participation. Demographic data about participants is presented in Table 1. No systematic dropout pattern is observed taking into account these characteristics as there is no difference between them comparing dropouts and those who participated in both phases of the study.

Table 1. Demographic characteristics of participants

\begin{tabular}{l|c|c|c}
\hline & $\begin{array}{c}\text { First phase } \\
(\mathrm{N}=29)\end{array}$ & $\begin{array}{c}\text { Second phase } \\
(\mathrm{n}=19)\end{array}$ & $\begin{array}{c}\text { Dropouts } \\
(\mathrm{n}=10)\end{array}$ \\
\hline Mean age, years (SD) & $27.58(1.32)$ & $28.42(3.11)$ & $27.44(3.37)$ \\
Average clinical experience, years (SD) & $2.11(.98)$ & $3.02(1.12)$ & $2.4(.96)$ \\
$\quad 1^{\text {st }}$ year residents, $\mathrm{n}(\%)$ & $8(27.59)$ & - & $2(20)$ \\
$2^{\text {nd }}$ year residents, $\mathrm{n}(\%)$ & $10(34.48)$ & $6(31.58)$ & $4(40)$ \\
$3^{\text {rd }}$ year residents, $\mathrm{n}(\%)$ & $11(37.93)$ & $6(31.58)$ & $4(40)$ \\
$4^{\text {th }}$ year residents, $\mathrm{n}(\%)$ & - & $7(36.84)$ & - \\
Gender & & & \\
$\quad$ Male, $\mathrm{n}(\%)$ & $12(41.39)$ & $8(42.11)$ & $4(40)$ \\
Female, $\mathrm{n}(\%)$ & $17(58.61)$ & $11(57.89)$ & $6(60)$ \\
\hline
\end{tabular}




\section{Materials}

Medical vignettes. Six medical vignettes were created specifically for this research. Example of a vignette is shown in Table 2 (note: guidelines illustrate an optimal way of thinking to reach a correct decision and were not presented to participants. Guidelines were further used by experts in the field of anesthesiology to evaluate participants' answers). Specific features of every vignette are presented in Table 3. All vignettes met two criteria: 1 ) the content of vignettes required making quick decisions and taking immediate actions in order to provide emergency medical care; 2) vignettes provoked ambiguity (i.e. it is possible to consider different causes of patients' current condition and different alternative diagnoses. However, only some of the possible alternatives are correct). All vignettes were divided into four critical parts each requiring to make a certain decision.

Table 2. Example of a vignette and guidelines for correct decision making response

\begin{tabular}{|c|c|}
\hline Example vignette & Guidelines \\
\hline $\begin{array}{l}\text { 1. You are about to perform an anesthesia } \\
\text { on } 50 \text { years old man who has an abdominal } \\
\text { wall hernia and is being prepared for plastic } \\
\text { operation. } \\
\text { Patient has a beard and moustache. His } \\
\text { height - } 172 \mathrm{~cm} \text {, weight - } 118 \mathrm{~kg} \text {. According } \\
\text { to the patient, he has no serious illnesses that } \\
\text { might be related to his current condition. } \\
20 \text { years ago, the patient had a general anes- } \\
\text { thesia for a knee arthroscopy; according to } \\
\text { him, arthroscopy as well as general anesthe- } \\
\text { sia went just fine, without additional compli- } \\
\text { cations. } \\
\text { Patients'BP at the moment is } 145 / 82 \text { mmHg, } \\
\text { HR- } 78 \text { bpm, saturation - } 98 \% \text {. What are your } \\
\text { steps for a further patient evaluation? How } \\
\text { are you going to prepare for the upcoming } \\
\text { anesthesia? } \\
1.1 \text {. You decided to start anesthesia. After } \\
\text { injecting propofol, you are trying to ven- } \\
\text { tilate the patient using a face mask. Since } \\
\text { the mask does not fit properly, ventilation } \\
\text { becomes difficult to perform. What actions } \\
\text { are you going to take next? }\end{array}$ & $\begin{array}{l}\text { 1. Patient is obese (BMI - 39.5), therefore, } \\
\text { problems regarding the direct laryngoscopy } \\
\text { might appear. Patient also has a beard, which } \\
\text { might hamper an adequate mask fit on a face } \\
\text { and therefore cause ventilation problems. } \\
\text { The fact that the patient had general anes- } \\
\text { thesia in the past is encouraging, however, } \\
\text { anesthesiologist must be cautious, because } \\
\text { patients' anatomy since } 20 \text { years ago could } \\
\text { have slightly changed. } \\
\text { It is required to make a basic airway assess- } \\
\text { ment. Even though there is no test that is } \\
\text { more important than others, most anesthe- } \\
\text { siologists apply Mallampati test, also exam- } \\
\text { ine patients' thyromental distance and neck } \\
\text { mobility. Additional examinations might in- } \\
\text { clude opening of the mouth and front teeth } \\
\text { protruding. } \\
1.1 \text {. and } 1.2 \text {. Faced with intubation prob- } \\
\text { lems, anesthesiologist should try other reli- } \\
\text { able techniques. The most common backup } \\
\text { plan in the case of direct laryngoscopy is to } \\
\text { try to push larynx from the outside yourself } \\
\text { or to ask an experienced assistant to do it. }\end{array}$ \\
\hline
\end{tabular}


1.2. Anesthesia is initiated: propofol and rocuronium is injected. 3 minutes after ventilation using a face mask, you perform a direct laryngoscopy with Macintoch laryngoscope blade (size 3 ). Only the edge of an epiglottis can be seen. Patients' BP 110/78 mmHg, HR - 64 bpm, saturation $96 \%$. What actions are you going to take next?

1.3. Your actions end up with same results only the edge of an epiglottis can be seen. Patients' BP - 100/72 mmHg, HR - 58 bpm, saturation $-86 \%$. What actions are you going to take next and why?
The next step - try changing patients' head position, laryngoscope blade size or a person who is performing an intubation. Regarding an obese patient, situation can be also improved by lifting head (putting few sheets under the head or lifting the bed-head). Some of the times, straight laryngoscope lifts the epiglottis better than a curved one. If none of that works - call for help!

In a case of a problematic ventilation, try to apply LMA. This method is internationally included in the standard algorithms created to deal with respiratory problems.

1.3. Experienced anesthesiologist might try to intubate patient blindly without seeing the glottis (using the string for an intubation tube and bending its tip). Other possible methods: bougie, optical laryngoscopes, flexible optic bronchoscope, LMA. Waking the patient and postponing the operation might also be an option. In this case, you will have to ensure the airway until reversal procedure can be done.

Table 3. Case specific features of medical vignettes

\begin{tabular}{c|l}
\hline Vignette & \multicolumn{1}{c}{ Case specific features } \\
\hline No.1 & $\begin{array}{l}\text { (a) patient's oxygen saturation drops by at least 10\% } \\
\text { (b) patient is difficult to ventilate }\end{array}$ \\
\hline No.2 & $\begin{array}{l}\text { (a) patient's arterial blood pressure drops by at least 45\% } \\
\text { (b) patient has no pulse }\end{array}$ \\
\hline No.3 & $\begin{array}{l}\text { (a) patient's arterial blood pressure drops by at least 45\% } \\
\text { (b) it is difficult to perform venepuncture procedure }\end{array}$ \\
\hline No.4 & $\begin{array}{l}\text { (a) patient's arterial blood pressure drops by at least 45\% } \\
\text { (b) patient's state of consciousness starts to deteriorate due to impaired }\end{array}$ \\
\hline No.5 & $\begin{array}{l}\text { (a) patient lost his consciousness and has no pulse } \\
\text { (b) patient is allergic to procaine }\end{array}$ \\
\hline No.6 & $\begin{array}{l}\text { (a) patient's arterial blood pressure drops by at least 45\% } \\
\text { (b) patient's oxygen saturation reduces at least 10\% }\end{array}$
\end{tabular}


Different vignettes were used in the first and in the second phase of the study. Therefore, we asked an expert with 9 years of experience in anesthesiology to evaluate difficulty levels of all vignettes. The Wilcoxon Signed-ranks test indicated that three vignettes (used in the first phase of the study) and other three vignettes (used in the second phase of the study) do not differ significantly in their difficulty levels $(Z=-.040$, $\mathrm{p}=.968$ ).

Think-aloud protocol. Verbal information about participants' decision making process was gathered using Ericsson's and Simon's (1980, 1993) think-aloud protocol. We used it in accordance to authors' suggested criteria which allows us to avoid reactivity and thought explanation: 1) researcher does not provoke unnecessary communication with participants; 2 ) it is emphasised in the instruction that participants must not explain their thoughts and focus solely on the content of the vignettes; 3 ) in order to familiarize with requirements to think-aloud, participants are given to solve few simple tasks; 4) if participants stop expressing thoughts verbally, the researcher encourages him / her to continue to think-aloud.

\section{Procedure}

All residents who signed an informed consent to participate in the study were individually asked to solve three medical vignettes presented in written form. Participants were asked to read vignettes aloud and make their decisions expressing thoughts aloud. The time to make final decisions on each part of a vignette was limited to 60 seconds. Answers were recorded using a dictaphone.

This procedure with two sets of different medical vignettes was carried out identically in both phases of the study.

\section{Data analysis}

Data recorded were transcribed and processed applying quantitative content analysis which was performed independently by two members of the research group. A theme (i.e. sentence or groups of sentences containing one and the same thought) was chosen as the unit of quantitative content analysis. Specific criteria were discerned before the 
analysis in order to identify three main groups of heuristics (Tversky \& Kahneman, 1974) used by anesthesiology residents during their decision making process:

1) Representativeness heuristic was identified when decisions were determined by information, which, according to participants, usually, typically or in most cases lead to specific evaluation of patients' condition and selection of treatment;

2) Availability heuristic was identified when participants named certain newly acquired knowledge or emotionally significant clinical experience (acquired in the past) which had an effect on final decision;

3) Anchoring and adjustment heuristic was identified when (a) participants' attention was focused on certain aspects of the medical vignette without considering other relevant alternatives or (b) participants did not adjust or modify their initial hypotheses when additional information was given.

Sufficient agreement (percentage of absolute agreement $-77.92 \%$ and Cohen's $K=.502, \mathrm{p}<.01$ ) between research members was obtained judging the use of different heuristics. In order to ensure high validity of results that concern anesthesiologists' use of heuristics, in a subsequent statistical analysis, we used only the data that had been evaluated identically by both raters ( 487 cases out of 625 across both the first and the second phase of the study).

The appropriateness of participants' answers was evaluated independently by two experts with 8 years of experience in anesthesiology using a 0-10 point scale. In order to identify cognitive errors made, experts' ratings were grouped: (a) ratings equal to or higher than 5 indicate that participants' decisions were more or less appropriate medically; (b) ratings lower than 5 indicate that participants' decisions were erroneous, i.e. fail to ensure appropriate provision of emergency medical care. Sufficient agreement $(I C C=.683$ ) between experts was obtained. Means of experts' ratings were used in a subsequent statistical analysis.

Statistical computations were performed with IBM SPSS 21 software. As distributions of all variables were not normal, we used non-parametric tests of statistical analysis. To evaluate the dynamics of anesthesiology residents' use of heuristics according to gained clinical experience, we compared the number of used heuristics and appropriateness of made 
decisions between the first and the second phase of the study with Wilcoxon Signed-rank test. Mann-Whitney $U$ test was used to compare the appropriateness of made decisions according to the type of decision making strategy (heuristic vs. not heuristic, anchoring and adjustment vs. not heuristic). Finally, to compare the overall number of thoughts and heuristic thoughts between the first and the second phase of the study, we used $x^{2}$ goodness of fit test.

\section{RESULTS}

\section{Number and type of used heuristics}

A Wilcoxon Signed-ranks test indicated that there was no significant difference between the total number of used heuristics per vignette in the first $(M d n=4)$ and the second phase $(M d n=3)$ of the study, $Z=.67$, $\mathrm{p}=.25$.

Descriptive data of the quantitative content analysis is presented in Table 4.

Table 4. The number of thoughts, heuristic thoughts, and erroneous heuristic thoughts across both phases of the study

\begin{tabular}{|c|c|c|c|c|}
\hline Phase & Vignette & Thoughts & Heuristic thoughts & $\begin{array}{c}\text { Erroneous heuristic } \\
\text { thoughts }\end{array}$ \\
\hline \multirow{4}{*}{$1^{\text {st }}$ phase } & No. 2 . & 92 & 30 & 9 \\
\hline & No. 5. & 81 & 25 & 9 \\
\hline & No. 6. & 84 & 29 & 10 \\
\hline & Overall & 257 (100\%) & 84 (33.33\%) & 28 (10.89\%) \\
\hline \multirow{4}{*}{$2^{\text {nd }}$ phase } & No. 1. & 76 & 27 & 9 \\
\hline & No. 3. & 71 & 22 & 5 \\
\hline & No. 4. & 83 & 26 & 9 \\
\hline & Overall & 230 (100\%) & 75 (32.61\%) & $23(10 \%)$ \\
\hline
\end{tabular}


Results of quantitative content analysis showed that the overall frequency of the use of heuristics $\left(x^{2}(1)=.002, p=.966\right)$ as well as erroneous heuristic thoughts $\left(x^{2}(1)=.240, p=.624\right)$ did not differ significantly comparing the first and the second phase of the study.

To evaluate the dynamics of the use of heuristics by anesthesiology residents according to gained clinical experience, we conducted a more detailed analysis directed towards different types of heuristics. Results showed that in the first as well as in the second phase of the study, residents used anchoring and adjustment heuristic the most (see Fig. 1). It is also important to note the specific change in the use of different heuristics during the study: compared to the first phase, in the second phase of the study, the frequency of the use of anchoring and adjustment heuristic increased $\left(x^{2}(1)=25.995, p<.001\right)$, while the frequency of the use of the availability heuristic decreased $\left(x^{2}(1)=25.267, p<.001\right)$.

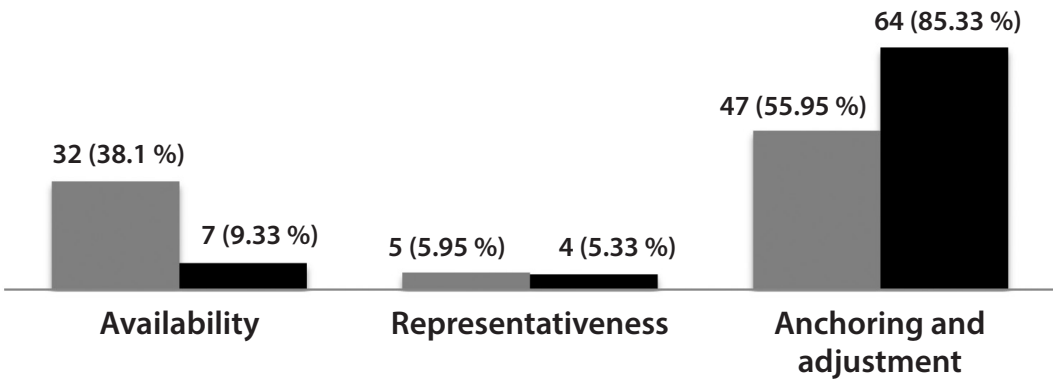

First phase Second phase

Figure 1. The distribution of frequency in the use of different heuristics in the first and in the second phase of the study

\section{Appropriateness of made decisions}

A Wilcoxon Signed-ranks test indicated that there was no significant difference between the appropriateness of made decisions in the first $(M d n=6.25)$ and the second phase $(M d n=6.58)$ of the study, $Z=-1.2$, $\mathrm{p}=.12$.

We also compared the appropriateness of the made decisions according to whether heuristics were used or not (see Table 5). 
Table 5. Appropriateness of made decisions when heuristics were and were not used

\begin{tabular}{c|c|c|c}
\hline \multirow{2}{*}{ Phase } & \multirow{2}{*}{ Vignette } & \multicolumn{2}{|c}{ Mean score } \\
\cline { 3 - 4 } & & No heuristics used & Heuristic used \\
\hline \multirow{3}{*}{$1^{\text {st }}$ phase } & No. 2. & $7.38(\mathrm{SD}=2.09), \mathrm{n}=59$ & $6.92(\mathrm{SD}=2.18), \mathrm{n}=28$ \\
& No. 5. & $5.45(\mathrm{SD}=2.64), \mathrm{n}=61$ & $5.48(\mathrm{SD}=1.92), \mathrm{n}=23$ \\
& No. 6. & $6.06(\mathrm{SD}=2.04), \mathrm{n}=53$ & $5.98(\mathrm{SD}=1.79), \mathrm{n}=33$ \\
\hline \multirow{3}{*}{$2^{\text {nd }}$ phase } & No. 1. & $6.72(\mathrm{SD}=1.14), \mathrm{n}=67$ & $6.04(\mathrm{SD}=.39), \mathrm{n}=10$ \\
& No. 3. & $7.33(\mathrm{SD}=1.4), \mathrm{n}=43$ & $7.18(\mathrm{SD}=2.01), \mathrm{n}=30$ \\
& No. 4. & $6.55(\mathrm{SD}=1.34), \mathrm{n}=45$ & $5.31(\mathrm{SD}=1.27), \mathrm{n}=35$ \\
\hline
\end{tabular}

The results of the first phase of the study showed that the appropriateness of the made decisions did not differ significantly across the cases when heuristics were used or not in all three medical vignettes. Different results were found analyzing the data of the second phase of the study. The Mann-Whitney test showed that less appropriate decisions were made in those cases when heuristics were used in the first $(U=218.500$, $Z=-1.784, p<.05 ; r=-.203)$ and in the fourth $(U=382.000, Z=-3.187$, $p<.05 ; r=-.356)$ medical vignettes compared to those cases when heuristics were not used.

Next, we focused our analysis on anchoring and adjustment as this heuristic was used most frequently and the data on other heuristics is not sufficient enough to make multiple comparisons (see Table 6).

Table 6. Appropriateness of made decisions when heuristics were not used and when anchoring and adjustment heuristic was used

\begin{tabular}{c|c|c|c}
\hline \multirow{2}{*}{ Phase } & \multirow{2}{*}{ Vignette } & Meanscore \\
\cline { 3 - 4 } & & No heuristics used & $\begin{array}{c}\text { Anchoring and adjustment } \\
\text { heuristic used }\end{array}$ \\
\hline \multirow{5}{*}{$1^{\text {st }}$ phase } & No. 2. & $7.38(\mathrm{SD}=2.09), \mathrm{n}=59$ & $7.38(\mathrm{SD}=1.81), \mathrm{n}=16$ \\
& No. 5. & $5.45(\mathrm{SD}=2.64), \mathrm{n}=61$ & $5.2(\mathrm{SD}=1.38), \mathrm{n}=9$ \\
& No. 6. & $6.06(\mathrm{SD}=2.04), \mathrm{n}=53$ & $6.11(\mathrm{SD}=1.76), \mathrm{n}=22$ \\
\hline \multirow{3}{*}{$2^{\text {nd }}$ phase } & No. 1. & $6.72(\mathrm{SD}=1.14), \mathrm{n}=67$ & $6.04(\mathrm{SD}=.39), \mathrm{n}=10$ \\
& No. 3. & $7.33(\mathrm{SD}=1.4), \mathrm{n}=43$ & $7.16(\mathrm{SD}=2.01), \mathrm{n}=25$ \\
& No. 4. & $6.55(\mathrm{SD}=1.34), \mathrm{n}=45$ & $5.28(\mathrm{SD}=1.27), \mathrm{n}=29$ \\
\hline
\end{tabular}


The results of the first phase of the study showed that the appropriateness of the made decisions did not differ significantly in all three medical vignettes according to whether anchoring and adjustment was used or no heuristics were used. Different results were found analyzing the data on the second phase of the study. The Mann-Whitney test showed that residents who used anchoring and adjustment heuristic made less appropriate decisions (e.g. "...l just think how to conduct an anesthesia. So... Because it is a 50-year-old patient, I will check if ECG was performed; I will check the results of all examinations. If the results are normal, preparation will be standard. I do not know... For anesthesia, I will use propofol, esmeron and fentanyl.") in the first $(U=218.500, Z=-1.784$, $p<.05 ; r=-.203)$ and in the fourth $(U=371.000, Z=-3.343, p<.05$; $r=-.389$ ) medical vignettes compared to those who did not use heuristicsat all.

\section{STUDY 2}

\section{METHODS}

\section{Participants}

Participants included 31 anesthesiology residents from Hospital of Lithuanian University of Health Sciences Kaunas Clinics and Vilnius University hospital Santariskiu Clinics who did not participate in the first study.

Mean participants' age was 28.46 years $(S D=3.53)$, average clinical experience -2.62 years $(S D=1.05)$. There were 17 junior $\left(1^{\text {st }}\right.$ year -4 , $2^{\text {nd }}$ year -13$)$ and 14 senior ( $3^{\text {rd }}$ year $-5,4^{\text {th }}$ year -9$)$ residents.

\section{Materials}

Some of the materials which were used in the study 1 (i.e. three [no. 2 , no. 3, and no. 4] randomly chosen medical vignettes from the first study and think-aloud protocol) were also used in the second study.

Stress induction. Cold pressor test (CPT) was used to induce an acute stress. CPT requires participants to immerse one hand into an ice-cold $\left(0-4^{\circ} \mathrm{C}\right)$ water and keep it there for 3 minutes. Before and after the CPT, 
participants were asked to evaluate their stress level on a $0-100 \%$ scale ( $0 \%$ - not stressed at all, 50\% - moderately stressed, $100 \%$ - extremely stressed). Studies show that CPT activates the sympathetic nervous system (Deuter et al., 2012). We assume that CPT (as a tool to provoke acute physiological stress) has an impact on changes in participants' hearth rate variability (HRV). Specifically, we expect a decrease in HRV (Chuang, Han \& Young, 2009), which would reflect the use of participants' autonomic nervous system in order to cope with physiological stress. To our knowledge, no study to date has proved that the CPT method (or decreased HRV) reflects the stress of clinical crises. However, results of Rieger, Stoll, Kreuzfeld, Behrens and Weippert (2014) showed that surgeons who experienced intraoperative stress had a decreased HRV as a result. Therefore, we believe that CPT (provoking decrease in HRV) can be used as a surrogate for inducing stress experienced in clinical crises.

Measures of physiological reactions. Physiological data were registered using "Biopac Student Lab PRO 3.7.3" software and "Biopac Systems" MP36 hardware for data storage. Heart rate was registered using a finger plethysmograph. Software was configured in two ways: 1) coefficient of signal amplification was set to 5,$000 ; 2$ ) in order to reduce artefacts, a filter (from .05 to $66.5 \mathrm{~Hz}$ ) was set. Therefore, participants' hearth rate was registered within this range.

\section{Procedure}

Participants signed an informed consent form to take part in the study. In the beginning, participants evaluated stress levels for the first time. Later on, participants' heart rate was registered for 3 minutes under resting conditions (finger plethysmograph attached to the ring finger of the dominant hand). Then participants were exposed to CPT (the nondominant hand was immersed into the cold water) after which they evaluated stress levels for the second time. Finally, participants' heart rate was registered once more for 3 minutes. After this procedure, participants were asked to solve three medical vignettes under the same conditions as in the first study. 


\section{Data analysis}

Quantitative content analysis (according to the same criteria as in the first study) was carried out independently by two research group members. Sufficient agreement (percentage of absolute agreement $84.04 \%$ and Cohen's $k=.611, p<.01$ ) was obtained judging the use of different heuristics. Again, in order to ensure a high validity of results that concern anesthesiologists' use of heuristics, in a subsequent statistical analysis, we used only the data that had been evaluated identically by both raters (i.e. 374 cases out of 445 ).

The appropriateness of participants' answers was also evaluated independently by two experts with 8 years of experience in anesthesiology using a 0-10 point scale as in the first study. Sufficient agreement (ICC $=.686$ ) between experts was obtained. Means of experts' ratings were used in a subsequent statistical analysis.

Data of participants' physiological reactions was analyzed with "Biopac Student Lab PRO 3.7.3" and "Kubios HRV 2.1" software (HRV was assessed using the time-domain analysis). Statistical computations were performed using IBM SPSS 21 software. Distributions of all variables were normal, therefore, we used parametric tests of statistical analysis. To evaluate the effect of the acute stress induction, we compared participants' HRV and stress level ratings before and after the CPT using the paired sample t-test. To evaluate the use of heuristics by anesthesiology residents under stressful conditions, we applied one-way ANOVA trend analysis to compare the appropriateness of made decisions according to the number of heuristics used in every vignette.

\section{RESULTS}

\section{Preliminary analysis: effect of the acute stress induction}

CPT was used to induce acute stress. Before and after the CPT, we registered participants' heart rate (which was later used to calculate HRV, the physiological estimate of stress). Paired sample t-test was conducted to compare the average HRV (ms) before and after the CPT. Average HRV after the CPT $(M=61.83 \mathrm{~ms}, \mathrm{SD}=18.79)$ was significantly lower compared to average HRV before the CPT ( $\mathrm{M}=67.03 \mathrm{~ms}, \mathrm{SD}=23.58)$; $\mathrm{t}(30)=2.1, \mathrm{p}<.05$. 
Participants were also asked to evaluate their stress level before and after the CPT. Paired sample t-test was conducted to compare ratings of stress level. The average of subjective ratings of the stress level after the CPT ( $M=36.13 \mathrm{~ms}, \mathrm{SD}=20.6$ ) was significantly higher compared to ratings before the $\mathrm{CPT}(\mathrm{M}=19.67 \mathrm{~ms}, \mathrm{SD}=17.65) ; \mathrm{t}(30)=5.03, \mathrm{p}<.05$.

\section{Heuristics use under stressful conditions}

Results of quantitative content analysis showed that $37.43 \%$ of anesthesiology residents' thoughts (140 cases out of 374 ) were identified as heuristic. In addition, $9.28 \%$ of these heuristic thoughts (13 cases out of 140) resulted in cognitive errors. Detailed information about the frequency of the use of particular heuristics is presented in Figure 2.

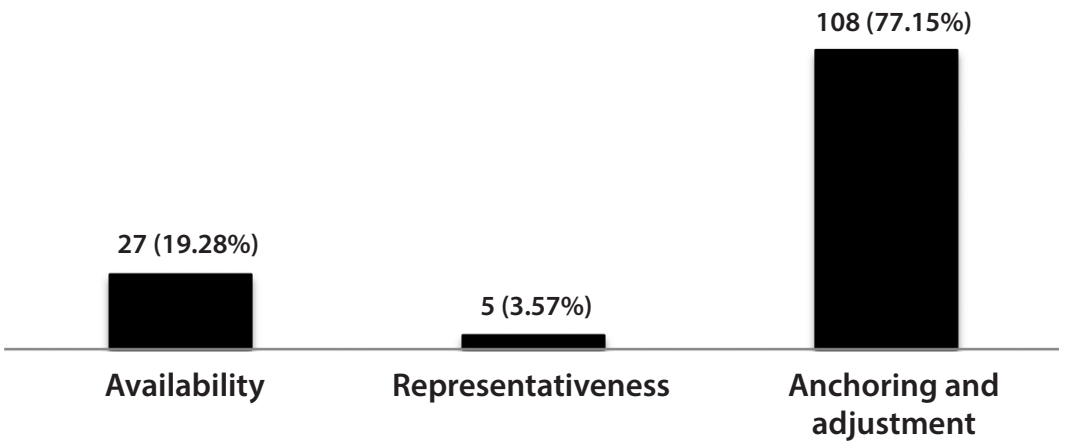

Figure 2. The distribution of frequencies in the use of heuristics

ANOVA (for every medical vignette separately) was conducted to examine the effect of the total number of used heuristics in a vignette on the appropriateness of residents' decisions.

Medical vignette No. 2: variances between groups using different number of heuristics are homogeneous (Levene $F(3,27)=2.758, p>.05$ ). There was no significant effect of the number of used heuristics on the appropriateness of made decisions $(F(3,27)=1.339, p=.283)$.

Medical vignette No. 3: variances between groups using different number of heuristics are homogeneous (Levene $F(2,28)=1.303, p>.05$ ). Significant effect of the number of used heuristics was found on the 
appropriateness of made decisions $(F(2,28)=8.029, p<.05)$. This effect can be best described by a quadratic trend $(F(1,28)=14.513, p<.05)$ (Figure 3).

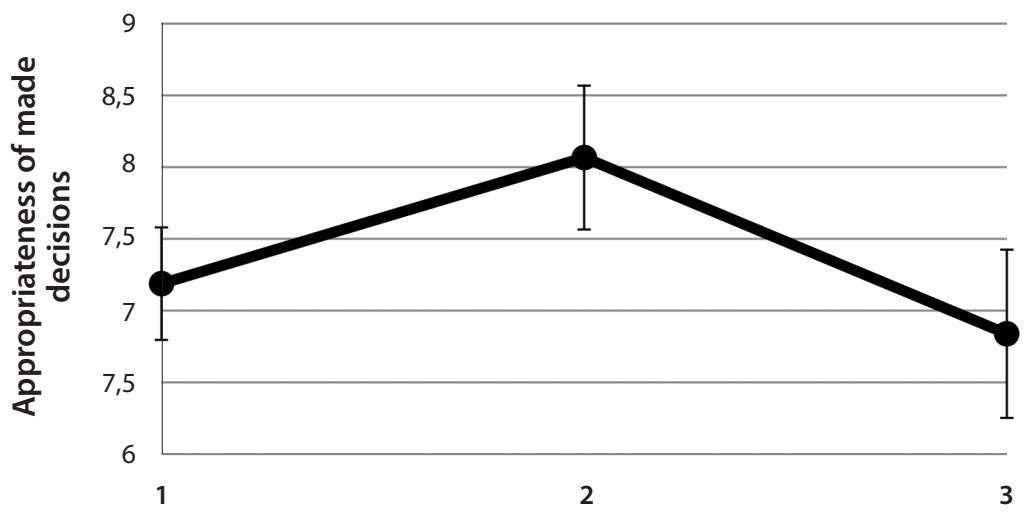

The number of used heuristics in a vignette

Figure 3. The appropriateness of made decisions according to the number of used heuristics in a third medical vignette

A Bonferroni post-hoc test revealed that those subjects who used one $(M=7.19, S D=.509, p<.05)$ or three $(M=6.84, S D=.83, p<.01)$ heuristics made statistically significantly less appropriate decisions compared to those who used two $(M=8.07, S D=.82)$ heuristics. There was no statistically significant differences between subjects, who used one and three heuristics $(p=1)$.

Medical vignette No. 4: variances between groups using different number of heuristics are homogeneous (Levene $F(3,27)=.431, p>.05$ ). Significant effect of the number of used heuristics was found on the appropriateness of made decisions $(F(3,27)=5.082 p<.05)$. This effect can also be best described by a quadratic trend $(F(1,27)=12.831$, $\mathrm{p}<.05$ ) (Figure 4). 


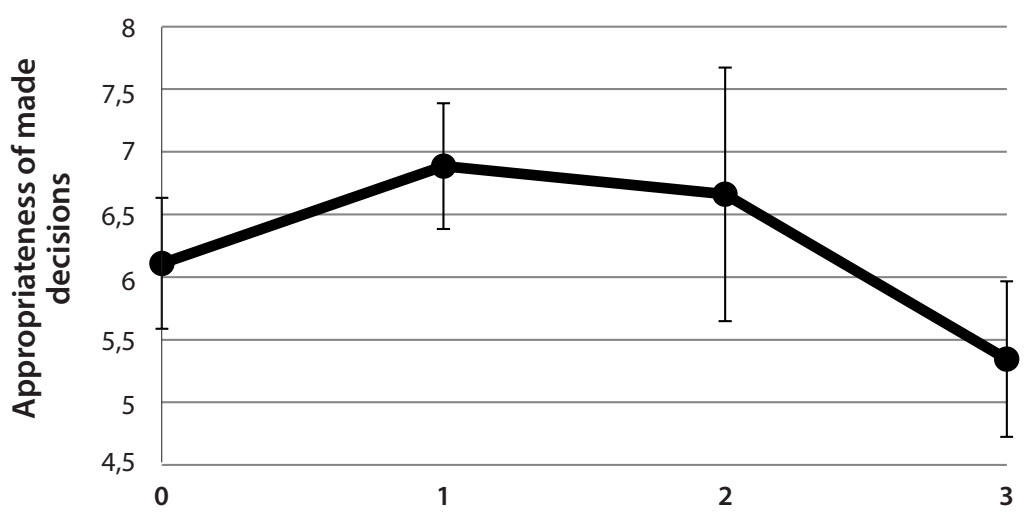

The number of used heuristics in a vignette

Figure 4. The appropriateness of made decisions according to the number of used heuristics in a fourth medical vignette

A Bonferroni post-hoc test revealed that those subjects who used three $(M=5.35, S D=.49)$ heuristics, made statistically significantly less appropriate decisions compared to those who used one $(M=6.89$, $\mathrm{SD}=.75, \mathrm{p}<.01)$ or two $(\mathrm{M}=6.67 \mathrm{SD}=1.09, \mathrm{p}<.05)$ heuristics. There were no statistically significant differences between other groups $(p>.05)$.

\section{GENERAL DISCUSSION}

\section{STUDY 1}

Results of the first study broaden the understanding of anesthesiologists' use of heuristics in two ways. First of all, we were able to identify anesthesiologists' use of heuristics at micro (thought) level. Previous studies (Stiegler et al., 2012) examined anesthesiologists' use of heuristics at macro level, i.e. observing and ascribing only one occurrence of one type of heuristic for each separate decision making session. Thus, information about the repeated use of the same heuristic during the same session was lost. The results of our first study indicate that regardless of acquired experience in the field of anesthesiology, about one-third 
of residents' thoughts solving emergency care problems are manifested as heuristics. Also, in about two-thirds of cases, appropriate decisions were made when heuristics were used to form final judgments. Nevertheless, cognitive errors, i.e. erroneous decision making, were evident in about 10 percent of residents' thoughts.

Secondly, the results of our longitudinal (within-subjects design) study shed some light on the dynamics of anesthesiologists' use of different heuristics. Previous between-subjects design studies (Mamede et al., 2010) were restricted only to the examination of the use of heuristics between different experimental groups. Moreover, such studies usually focus on only one instead of a few heuristics. The results of our study showed that acquired medical experience had an impact on the change of the use of different heuristics. From a standpoint of cognitive psychology, qualitatively new scripts are formed as doctors gain more medical experience (Schmidt et al., 1990; Schmidt \& Boshuizen, 1993; Charlin et al., 2007). When doctors face highly familiar medical situations, they are more likely to process scripts' information with type 1 heuristic cognitive processes (Croskerry, 2009b; Evans \& Stanovich, 2013). It is assumed that with learning and growing medical experience, the number of scripts increases; this in turn enables an easier access to heuristic processes (Croskerry, 2009a). Our study showed certain tendencies in the use of specific heuristics according to gained medical experience, i.e. anesthesiology residents used availability heuristic less, and anchoring and adjustment heuristic more as their medical experience increased. These results can be explained with regard to different characteristics of these heuristics. Availability heuristic is commonly used when decisions are made relying on (a) emotionally laden experience from the past or (b) relying on newly acquired knowledge which can be easily remembered. In both cases, the principle that characterizes the tendency to consider easily remembered events as occurring more often is evident. On the other hand, anchoring and adjustment is used when doctors or residents focus their attention too much only on a very few certain cues about patient's medical condition (Croskerry, 2002). It is probable that when residents have relatively little experience in their field, they are more likely to activate newly formed prototypic decision making patterns. Thus, their decisions are more likely to be affected by the 
availability heuristic. Anchoring and adjustment heuristic still plays a crucial role in decision making, because residents' knowledge on general medicine might still be very salient. However, as a more specific experience in the anesthesiology field is acquired, the relatively stable knowledge base becomes more elaborated. Therefore, with gradual development, it becomes an even greater anchor. The shift in the residents' use of heuristics could have also occurred because of the slight differences in the content of vignettes used in the first and in the second phase of the study. However, this explanation is only partial, because (1) some of the features in different vignettes were similar (Table 4) and (2) vignettes did not differ in difficulty levels across both phases of the study.

Results of the second phase of the study indicate that residents' made less appropriate decisions when using anchoring and adjustment heuristic compared to the cases when heuristics were not used. This tendency occurred in a context of two out of three medical vignettes. Therefore, it can be identified under what specific circumstances anchoring and adjustment was being used falsely: (a) when the patient's arterial blood pressure drops by at least 45\% (vignette no. 1 and no. 4); (b) when patient's state of consciousness starts to deteriorate due to impaired blood circulation (vignette no. 4); (c) when patient's oxygen saturation drops by at least $10 \%$ (vignette no. 1); (d) when the resident is faced with difficulties in attempting to ventilate the patient (vignette no. 1). It can be assumed that an inappropriate use of anchoring and adjustment in the second phase of the study is related to an increase of its use, which occurred in tandem with the decrease in the use of availability heuristic. This could mean that particular medical knowledge, upon which the use of availability heuristic was replaced by anchoring and adjustment, is not stable enough to account for appropriate heuristically generated decisions. Therefore, the formation of a more stable and reliable knowledge base containing a larger number of qualitatively different scripts would be a good reason to expect higher-quality decisions. However, further empirical studies are needed to test these assumptions regarding dynamics of the use of heuristics and their relationship with the appropriateness of made decisions in anesthesiology. 


\section{STUDY 2}

It is known that the CPT elicits sympathetic nervous system activity (Deuter et al., 2012) and excitates physiological stress. Results of our study shows a decrease in residents HRV after the CPT which means that resources of the autonomic nervous system were utilized in order to cope with induced physiological stress.

Analysis of the appropriateness of residents' decisions according to number of used heuristics yielded interesting results. It was found that the appropriateness of made decisions reaches the peak when no more than two heuristics are used. In the light of dual process theories, these results could be interpreted as reflecting an effective and adaptive interaction between type 1 and type 2 cognitive processes. On the one hand, certain cues in medical vignettes could have activated type 1 processes first, while more rational type 2 processes were involved only after the encounter of contradictory information. This pattern of interaction between type 1 and type 2 processes relies upon the meta-cognitive ability, which allows for more rational assessment of the content of working memory. On the other hand, a different pattern of interaction between type 1 and type 2 processes is possible: residents could have processed information in a rational way first and only after that engaged in heuristic decision making. In other words, rationally structured information (which satisfied certain cognitive scripts) was processed by the use of heuristics (Croskerry, 2009a, b). Relatively worse decisions, when no or more than two heuristics were used, can be explained by taking into account specific circumstances regarding emergency medical care. Rational decision making involving type 2 cognitive processes (i.e. without using heuristics) requires a considerable amount of time. In our study, residents were given a limited time to make their final decisions. Therefore, the appropriateness of made decisions could have worsened because not all information was processed thoroughly (even though the information was considered in a correct manner). In turn, the use of more than two heuristics may reduce the appropriateness of made decisions due to the increasing probability to commit a cognitive error. 
It should be noted that further empirical support is needed to confirm these results. Due to specific characteristics (small absolute number of anesthesiology residents in Lithuania and their busy schedule including night shifts) of research contingent we decided to not include control (no stress) group in our study.

$$
\text { *** }
$$

The results of both studies bring our attention to the need for further discussions about the opportunities to improve existing residency program in anesthesiology regarding the improvement in the residents' meta-cognitive ability. There is empirical evidence suggesting that educational seminars on heuristics and cognitive biases increase medical students' knowledge in medical decision-making area (Hershberger, Markert, Part, Cohen \& Finger, 1997). However, it is not clear whether gained knowledge can be efficiently applied to medical practice. Eva (2009) suggests that spaced training, considering its positive influence to long-term practical performance, may be a beneficial method used in order to help students transfer their knowledge into practice. Other methods that might help to improve long-term performance or an ability to effectively apply essential information from familiar to novel cases are limited feedback, contrastive and test-enhanced learning. Concentration on the possibilities to organize courses on information processing and decision making could be a good starting point as there are already universities in the world which have more than 10 years of experience in teaching this approach undergraduate medical students (Croskerry, 2003). Such courses could be targeted at the improvement of rational as well as heuristic information processing emphasising the interplay between type 2 and type 1 cognitive processes.

\section{Limitations and guidelines for further research}

Further studies in this field should pay attention to several things. There was only a 10 month interval between the first and the second phase of our first study. It is likely that this interval was insufficient to obtain fairly informative data on the dynamics of the use of heuristics. Therefore, further research examining quantitative and qualitative dynamics of decision making should focus on longer longitudinal studies allowing for more flexible division of time periods. Furthermore, 
a better understanding about the characteristics of anesthesiology specialists' decision making in accordance to their clinical experience could be sought by expanding the contingent of participants, i.e. involving anesthesiologists who have completed their residency.

In our second study, both times (before and after the CPT) we registered participants' heart rate only before solving medical vignettes. It is recommended for further studies to register participants' physiological reactions after solving each medical vignette. This approach could provide additional information about the dynamics of stress as well as capabilities to cope with it in situations requiring to make decisions in a context of emergency medical care. It is also worth noting that participants' physiological reactions were registered with a finger plethysmograph. However, more accurate information about the heart rhythm and HRV could be obtained using an electrocardiograph (Giardino, Lehrer \& Edelberg, 2002; Schafer \& Vagedes, 2013). Moreover, additional information about the stress levels could be obtained recording the changes in the level of cortisol.

Due to a relatively small sample size and dropouts (first study), our results should be considered preliminary and remain to be replicated in a more ecologically valid environment. Participants did not have to perform any real actions while solving medical vignettes, only verbal information was collected using the think-aloud protocol. We believe that the application of the patient simulator which would allow participants to take an action instead could yield more ecologically valid results regarding the real practice of anesthesiology specialists.

\section{CONCLUSIONS}

Results of both studies indicate certain frequencies in the use of heuristics and cognitive errors that are characteristic to the residents of anesthesiology in a context of situations requiring emergency medical care, i.e. (a) 32-38 percent of residents' decision making process manifested in a form of heuristics; (b) 3-11 percent of residents' decision making process manifested in a form of cognitive errors. Results of the first study showed that in accordance to residents' gained experience in the field of anesthesiology, their use of the availability heuristic decreased and the use of anchoring and adjustment heuristic increased. 


\section{References}

Buckingham, C. D., Adams, A. (2000). Classifying clinical decision making: interpreting nursing intuition, heuristics and medical diagnosis. Journal of Advanced Nursing, 32(4), 990-998.

Charlin, B., Boshuizen, H. P. A., Custers, E. J., Feltovich, P. J (2007). Scripts and clinical reasoning. Medical Education, 41, 1178-1184.

Chuang, C. Y., Han, W. R., Young, S. T. (2009). Heart rate variability response to stressful event in healthy subjects. IFMBE Proceedings, 23, 378-380.

Croskerry, P. (2002). Achieving quality in clinical decision making: Cognitive strategies and detection of bias. Academic Emergency Medicine, 9(11), 1184-1204.

Croskerry, P. (2003). Cognitive forcing strategies in clinical decision making. Annals of Emergency Medicine, 41(1), 110-120.

Croskerry, P. (2009a). A universal model of diagnostic reasoning. Academic medicine, 84(8), 1022-1028.

Croskerry, P. (2009b). Clinical cognition and diagnostic error: Applications of a Dual Process model of reasoning. Advances in Health Sciences Education: Theory and Practice, 14, 27-35.

Croskerry, P., Nimmo, G. R. (2011). Better clinical decision making and reducing diagnostic error. Journal of the Royal College of Physicians of Edinburgh, 41, 155-162.

Deuter, C. E., Kuehl, L. K., Blumenthal, T. D., Schulz, A., Oitzl, M. S, Schachinger, H. (2012) Effects of cold pressor stress on the human startle response. PLOS ONE, 7(11), 1-7.

Ericsson, K. A., Simon, H. A. (1993). Protocol Analysis: Verbal Reports as Data (2 ${ }^{\text {nd }}$ ed.). Cambridge, MA: The MIT Press.

Ericsson, K. A., Simon, H. A. (1980). Verbal reports as data. Psychological Review, 87(3), 215-251.

Eva, K. W. (2009). Diagnostic error in medical education: where wrongs can make rights. Advances in Health Sciences Education: Theory and Practice, 14, 71-81.

Evans, J. St. B. T. (1984). Heuristic and analytic processes in reasoning. British Journal of Psychology, 75, 451-468.

Evans, J. St. B. T. (2008). Dual-Processing accounts of reasoning, judgment, and social cognition. Annual Review of Psychology, 59, 255-278.

Evans, J. St. B. T., Stanovich, K. E. (2013). Dual-Process theories of higher cognition: Advancing the debate. Perspectives on Psychological Science, 8(3), 223-241.

Giardino, N. D., Lehrer, P. M., Edelberg, R. (2002). Comparison of finger plethysmograph to ECG in the measurement of heart rate variability. Psychophysiology, 39(2), 246-253.

Hershberger, P. J., Markert, R. J., Part, H. M., Cohen, S. M., Finger, W. W. (1997). Understanding and Addressing Cognitive Bias in medical Education. Advances in Health Sciences Education: Theory and Practice, 1, 221-226.

Kahneman, D. A. (2003). Perspective on judgment and choice, mapping bounded rationality. American Psychologist, 58(9), 697-720.

Kain, Z. N., Chan, K. M., Katz, J. D., Nigam, A., Fleisher, L., Dolev, J., Rosenfeld, L. E. (2002). Anesthesiologists and acute perioperative stress: A Cohort Study. Anesthesia \& Analgesia, 95, 177-183.

Kim, J. J., Diamond, D. M. (2002). The stressed hippocampus, synaptic plasticity and lost memories. Nature Reviews Neuroscience, 3, 453-462.

Lieberman, M. D. (2000). Intuition: a social cognitive neuroscience approach. Psychological Bulletin, 126(1), 109-137. 
Lieberman, M. D. (2007). The X- and C-systems: The neural basis of reflexive and reflective social cognition. In E. Harmon-Jones, P. Winkelman (eds.), Fundamentals of Social Neuroscience. New York: Guilford. pp. 290-315.

Mamede, S., van Gog, T., van den Berge, K., Rikers, R. M. J. P., van Saase, J. L. C. M., van Guldener, C., Schmidt, H. G. (2010). Effect of availability bias and reflective reasoning on diagnostic accuracy among internal medicine residents. The Journal of the American Medical Association, 304(11), 1198-1203.

Marewski, J. N., Gigerenzer, G. (2012). Heuristic decision making in medicine. Dialogues in Clinical Neuroscience, 14(1), 77-89.

McLaughlin, K., Eva, K. W., Norman, G. R. (2014). Reexamining our bias against heuristics. Advances in Health Sciences Education: Theory and Practice, 19, 457-464.

Pruessner, J. C., Dedovic, K., Pruessner, M., Lord, C., Buss, C., Collins, L., Lupien, S. J. (2010). Stress regulation in the central nervous system: Evidence from structural and functional neuroimaging studies in human populations - 2008 Curt Richter award winner. Psychoneuroendocrinology, 35, 179-191.

Reyna, V. F., Brainerd, C. J. (1995). Fuzzy-trace theory: An interim synthesis. Learning and Individual Differences, 7(1), 1-75.

Rieger, A., Stoll, R., Kreuzfeld, S., Behrens, K., Weippert, M. (2014). Heart rate and heart rate variability as indirect markers of surgeons' intraoperative stress. International Archives of Occupational and Environmental Health, 87, 165-174.

Rumelhart, D. E., Ortony, A. (1977). The representation of knowledge in memory. In R. C. Anderson, R. J. Spiro, W. E. Montague (Eds.), Schooling and the acquisition of knowledge. Hillsdale, NJ: Erlbaum. pp. 99-135.

Schafer, A., Vagedes, J. (2013). How accurate is pulse rate variability as an estimate of heart rate variability? A review on studies comparing photoplethysmographic technology with an electrocardiogram. International Journal of Cardiology, 166(1), 15-29.

Schank, R. C., Abelson, R. P. (1977). Scripts, Plans, Goals and Understanding: An Inquiry Into Human Knowledge Structures. Hillsdale, New Jersey: Lawrence Erlbaum Associates.

Schank, R. C. (1982). Dynamic Memory: A theory of reminding and learning in computers and people. New York: Cambridge University Press.

Schmidt, H. G., Boshuizen, P. A. (1993). On acquiring expertise in medicine. Educational Psychology Review, 5(3), 205-221.

Schmidt, H. G., Norman, G. R., Boshuizen, P. A. (1990). A cognitive perspective on medical expertise: Theory and implications. Academic medicine, 65(10), 611-621.

Sloman, S. A. (1996). The empirical case for two systems of reasoning. Psychological Bulletin, 119(1), 3-22.

Starcke, K., Brand, M. (2012). Decision making under stress: A selective review. Neuroscience and Biobehavioral Reviews, 36, 1228-1248.

Stiegler, M. P., Neelankavil, J. P., Dhillon, A. (2012). Cognitive errors detected in anesthesiology: A Literature Review and Pilot Study. British Journal of Anaesthesia, 108(2), 229-235.

Stiegler, M. P., Tung, A. (2014). Cognitive processes in anesthesiology decision making. Anesthesiology, 120, 204-217.

Tversky, A., \& Kahneman, D. (1974). Judgment under uncertainty: Heuristics and biases. Science, 185(4157), 1124-1131. 


\title{
ANESTEZIOLOGIJOS-REANIMATOLOGIJOS REZIDENTU SPRENDIMŲ PRIĖMIMAS, TEIKIANT SKUBIĄ MEDICINOS PAGALBA
}

\author{
Tomas Maceina, Gintautas Valickas, Jūratė Šipylaitė \\ Vilniaus universitetas, Lietuva \\ Andrius Macas \\ Lietuvos sveikatos moksly̨ universitetas, Lietuva \\ Jevgenija Olševska \\ Anesteziologijos, intensyvios terapijos ir skausmo gydymo centras, Vilniaus universiteto ligoninė, \\ Santariškių klinikos, Lietuva \\ Pranas Puidokas \\ Všl Centro poliklinika, Lietuva
}

Santrauka. Moksliné problema. Teikdami skubią medicinos pagalbą, anesteziologijosreanimatologijos srityje besispecializuojantys rezidentai rizikuoja priimti klaidingus sprendimus, galinčius nulemti paciento mirti. Siekiant paaiškinti anesteziologijos-reanimatologijos rezidentų sprendimų prièmimo ypatumus, teikiant skubią medicinos pagalbą, kyla esminių problemų. Pavyzdžiui, neaišku, kokia yra euristikų, t. y. supaprastintų sprendimo prièmimo būdų, taikymo specifika anesteziologijos-reanimatologijos srityje. Be to, itin trūksta empirinių duomenų, galinčiu paaiškinti euristikų taikymo ypatumus, esant stresinèms situacijoms, taip pat ju dinamiką, keičiantis darbo stažui. Tikslas - išsiaiškinti anesteziologijosreanimatologijos rezidentų euristikų taikymo ypatumus, teikiant skubią medicinos pagalbą. Igyvendinant ši tikslą, atlikti du nepriklausomi tyrimai anesteziologijosreanimatologijos rezidentų euristikų taikymo ypatumams ịvertinti: a) didejjant darbo stažui, b) stresinėmis aplinkybėmis. Metodika. Pirma (tęstinio pobūdžio) tyrimą sudarè du etapai. Abiejų etapu metu rezidentai, ịvardydami savo mintis žodžiu, sprendè po tris panašaus sudètingumo medicinines situacijas. Antro tyrimo metu dalyviams taikyta "šalto vandens" užduotis, siekiant sukelti fiziologini stresą. Prieš šią užduoti ir po jos, naudojant pletizmografą, registruotas tyrimo dalyvių širdies ritmas. Vèliau esant tokioms sąlygoms, kaip ir pirmame tyrime, dalyviai sprendè tris medicinines situacijas. Tyrimo dalyvių atsakymus vertino du nepriklausomi ekspertai - gydytojai anesteziologai-reanimatologai. Rezultatai, išvados. Atlikta duomenų kiekybinè turinio analizè atskleidè, kad didèjant anesteziologijos-reanimatologijos rezidentų darbo stažui, mažèja pasiekiamumo ir didèja „inkaro“ euristiku taikymo dažnumas. Nustatyta, kad anesteziologijos-reanimatologijos rezidentai, taikydami ne daugiau kaip dvi euristikas, linkę priimti optimaliausius sprendimus, teikdami skubią medicinos pagalbą stresinėmis aplinkybėmis. Abiejų tyrimų rezultatai parodè, kad 32-38 proc. anesteziologijos-reanimatologijos rezidentų minčių, sprendžiant skubios medicinos pagalbos situacijas, pasireiškè kaip euristikos, o 3-11 proc. - kaip kognityvios klaidos.

Pagrindiniai žodžiai: sprendimų prièmimas, euristikos, mąstymo klaidos.

Received: 2016-02-09

Accepted: 2017-02-04 